\title{
ŽUVU TAUKŲ SVARBA SUNKIOS BŪKLĖS PACIENTŲ MODERNIAJAI PARENTERINEI MITYBAI
}

\author{
Dalia Adukauskienė, Akvilė Jurgelėnaitė, Tomas Vanagas \\ Lietuvos sveikatos moksly universiteto Medicinos akademijos Medicinos fakultetas
}

Raktažodžiai: parenterinè mityba, žuvų taukai, uždegimas, sepsis, kritinè būklè.

\begin{abstract}
Santrauka
Parenterinė mityba - būdas užtikrinti optimalią klinikinę mitybą, ypač kritinès būklès ir chirurginio profilio pacientams. Straipsnyje analizuojamos mokslinès studijos, atskleidžiančios parenterinių mišinių su žuvų taukais reikšmę sunkios būklès pacientų ligos baigčiai. Darbo tikslas - apžvelgti naujausių tyrimų išvadomis pagrisstą žuvų taukų vartojimo parenteriniuose mišiniuose vertę kritinès būklès pacientams ir pooperaciniu laikotarpiu. Tyrimo rezultatai parodè, jog ịvairių kritinių būklių atvejais tokie mišiniai padeda kontroliuoti uždegimą, kai jo požymiai itin ryškūs. Padaryta išvada, jog žuvų taukais papildytų parenterinių mišinių vartojimas susijęs su geresne kritinès būklès pacientų ligos baigtimi - gerèja imunologinių tyrimų rodmenys, mažeja infekcinių ligų dažnis, antibiotikų poreikis, trumpejja mechaninès ventiliacijos, gydymo intensyviosios terapijos, pooperaciniame skyriuje trukmè, gerèja išgyvenamumas. Pacientams vartoti ilgą laiką parenterinius mišinius su žuvų taukais saugu. Vakarų Europos šalių ligoninių duomenų analizè padejjo tyrejjams įvertinti šiuos mišinius farmakoekonominiu atžvilgiu: autoriai rado, jog vartojant tokius mišinius, galima sumažinti sunkios būklès pacientų gydymo išlaidas.
\end{abstract}

\section{Ivadas}

Mitybinių medžiagų trūkumas - aktuali medicinos problema, ypač kritinių būklių ir sunkių chirurginių susirgimų atvejais, kai energetinis poreikis didelis, o jo užtikrinimas dèl ịvairių priežasčių tampa nepakankamas [1,2]. Enterinès mitybos galimas šalutinis poveikis mažesnis, nei parenterinès, tačiau enteraliai koreguoti energijos trūkumą ne visuomet įmanoma [2,3]. Laiku neužtikrinus adekvataus klinikinio maitinimo, didejja mirštamumas, infekcinių ligų dažnis, ilgejja mechaninès ventiliacijos (toliau - MV) trukmé $[1,2,3]$, todèl būtina individualiai vertinti kiekvieno kritinès būklès paciento mitybos pobūdị ir, siekiant išvengti nepalankių pasekmių, tinkamu laiku skirti parenterinę mitybą.

Parenterinių mišinių (toliau - PM) tikslas - tiekti žmogui būtinąsias maistines medžiagas, apsaugant nuo mitybos nepakankamumo ar jị koreguojant, kai kiti būdai negalimi [1,4]. PM formulèse gausu junginių - angliavandenių, baltymų, lipidų, vitaminų, elektrolitų ir mineralų, būtinų palaikyti stabilias organizmo funkcijas $[4,5]$. Parenterinès mitybos metu šios medžiagos per intravenini periferinès ar centrinès venos kateterị patenka tiesiai ị kraujotaką, aplenkdamos virškinamaji traktą $[1,4,5]$.

Intraveninès lipidų emulsijos (toliau - IV LE) - sudedamoji PM dalis, užtikrinanti energetinius ląstelių poreikius, jų membranų stabilumą bei prostaglandinų, tromboksanų, leukotrienų gamybą [1,2,5]. Kadaise pirmieji PM buvo papildyti dekstroze, kurie užtikrino organizmo aprūpinimą energija, tačiau didino hiperglikemijos riziką, todèl rinkoje atsirado pirmosios IV LE, papildytos medvilnès sẻklų ar sojų aliejumi. Nors šiuo metu IV LE su medvilnès sèklų aliejumi rinkoje jau nėra, sojų aliejaus pagrindu pagaminti PM dar populiarūs $[5,6]$. Nuolat atliekamuose tyrimuose pastebèta jų potenciali žala dèl itin didelio $\omega-6$ polinesočiųu riebiuju rūgščių (toliau - PNRR) kiekio sojų aliejuje, iš kurių pagrindinè - linoleno rūgštis (toliau - LR) $[6,7,8]$. Dèl šios priežasties rinkoje atsirado PM, papildytų žuvų taukais $[2,6]$. Vartojant šiuos gaminius, pastebètas uždegimo slopinamasis poveikis, kuris buvo susietas su žuvų taukuose esančiomis $\omega-3$ PNRR [1,2].

Tyrimo tikslas - supažindinti su naujausių mokslinių studijų išvadomis apie PM, papildytų žuvų taukais, poveiki kritinès būklès ir chirurginio profilio pacientams, kai tikètina didžiausia uždegimo raiška. 


\section{Tyrimo medžiaga ir metodai}

Literatūros apžvalga atlikta remiantis paskelbtais moksliniais tyrimais elektroninèse duomenų bazėse: PubMed, ScienceDirect, Cochrane, Wiley, GoogleScholar, atrinkus straipsnius nuo 2003 iki 2019 metų. Iš viso atrinkti 31 straipsniai ir atlikta jų apžvalga. Šiame straipsnyje pateikiamos jų duomenų analizès išvados.

\section{Rezultatai}

Lipidų svarba ir skirtumai. Lipidai žinomi kaip pagrindinès ląstelès membranos dalys, kurios užtikrina kontroliuojamą pralaidumą, optimalų nervinių signalų perdavimą, tarpląstelinių ryšių susidarymą bei apsauginę funkcijas [5,6]. Visos šios savybės siejamos su cheminiais lipidų vienetais - riebiosiomis rūgštimis (toliau - RR), triacilgliceroliais ir fosfolipidais [5,9]. Lipidai svarbūs ir energetiniu požiūriu - juos skaidant iš $1 \mathrm{~g}$ išsiskiria apie $9 \mathrm{kcal}$ (1g glikogeno tik 4 kcal). Reikšminga ir tai, kad organizmas yra prisitaikęs kaupti lipidus, dèl to būtent jie yra pagrindinis žmogaus energetinis rezervas $[9,10]$. Šiuo metu vis aktualesnè problema - nepakankamas $\omega-3$ PNRR kiekis mityboje, ypač svarbi tautoms, kuriose tradiciškai žuvis, gausi $\omega-3$ PNRR, neužima didelès raciono dalies $[2,11]$. Nors istoriškai žmogaus mityboje didesnis $\omega$-6 PNRR kiekis visada buvo gaunamas iš augalų, dabar dar ir dèl aplinkos taršos gausesnis šiu junginių kiekis gali labiau skatinti uždegimo procesus ir iš to kylančių ligų riziką $[11,12]$. Iš $\omega-6$ PNRR linoleno rūgšties (toliau - LR) išskiriama arachidono rūgštis (toliau - AR) yra pagrindine AR kaskados sudedamoji dalis, kontroliuojanti apie 20 procesų per signalinius kelius, iš kurių svarbiausias - uždegimo [12,13]. Vartojant žuvų taukus, gaunama organizmui būtinujų RR - eikozapentaeno (toliau - EPR) ir dokozaheksaeno (toliau - DHR), kurios konkuruoja su AR kaskada $[9,12,13,14]$. Atliktos klinikinès studijos parode EPR ir DPR svarbą - žuvų taukai gali gerinti kritinès būklès pacientų ligos baigtị, todèl buvo pradèta gaminti PM, papildytus šiomis medžiagomis (santykis tarp $\omega-6$ PNRR ir žuvų taukų $\omega$-3 PNRR 2:1 arba 4:1) [2, 12, 13].

Žuvų taukai ir jų geba kontroliuoti pernelyg raiškias uždegimo reakcijas. Uždegimas yra viena iš daugelio organizmo atsakomujų reakcijų i patogenus, toksinus, dirginančias medžiagas ar pažeistas ląsteles $[15,16]$. Pirminè uždegimo funkcija yra šalinti priežastị sukèlusią pažaidą bei aktyvinti apsauginius mechanizmus, audinių regeneraciją, naikinti nekrotizavusias ląsteles, audinius [16,17]. Subalansuotas atsakas ị uždegimą yra labai naudingas fiziologinis mechanizmas, kuris saugo organizmą nuo infekcijos ir kitų
Žalojančių veiksnių, tačiau pernelyg ryškus uždegimas gali žaloti audinius, sukelti organų disfunkciją ir sepsio riziką $[15,16,17]$.

Pagal atsako trukmę ir intensyvumą, uždegimas gali būti ūminis ir lètinis. Jau 1992 m. Amerikos krūtinès gydytojų kolegija bei Amerikos intensyviosios terapijos draugija pristatė apibrezžtis, apibūdinančias sisteminị uždegiminio atsako sindromą (toliau - SUAS), sepsį, sunkų sepsį, sepsinį šoką ir dauginès organų disfunkcijos sindromą (toliau - DODS). Dèl naujos mokslinių tyrimų informacijos apie kitokią sepsio patogenezę, naujausiame tarptautiniame sutarime Sepsis-3 atsisakyta ankstesnès sepsio apibrèžties [17]. Anksčiau laikytasi nuostatos, kad SUAS yra nespecifiškas ir gali kilti išemijos, bet kokios kilmès uždegimo, traumos, infekcijos arba šių veiksnių kombinacijos atveju [17]. Sepsis yra sukèlèjo bei jo toksinų patekimo ị organizmą (kraują ir (ar) kitus audinius) ir naujojo sutarimo požiūriu paskelbto nesubalansuoto sisteminio atsako ị infekciją derinys, o sepsinis šokas - sepsio fone išliekanti hipotenzija, nepaisant adekvačios infuzoterapijos. SUAS, sepsio ir sepsinio šoko metu stebimas ženkliai didejjantis reaktyviojo deguonies ir uždegimo mediatorių kiekis, kartu su mažejjančiu antioksidantų aktyvumu, siejamas ir su nepakankama klinikine mityba sunkiai valdomo uždegiminio proceso požiūriu $[17,18]$. Norint išvengti nekontroliuojamo uždegimo keliamos žalos, gydant kritinès būklès pacientą, aktualu mažinti uždegimo reakciją katabolinėje ligos fazèje ir stiprinti natūralius imuninès apsaugos mechanizmus. Žuvų taukais papildytų PM reikšmé šiame procese priklauso nuo gausaus kiekio $\omega-3$ PNRR (EPR ir DHR) $[7,12,19]$. Šių PNRR aktyvuojama kaskada konkuruoja su AR, gamindama eikozanoidų kilmès mediatorius, kurie slopina iš $\mathrm{AR}$ besiformuojančius junginius - prostaglandinus, tromboksanus ir leukotrienus, žinomus kaip prouždegimo mediatorius, todèl uždegimo atsakas tampa labiau subalansuotas, ,fiziologiškesnis“ $[11$, $12,19,20]$.

Atrastos naujos lipidų mediatorių rūšys - rezolvinai, protektinai, marezinai ir lipoksinai praplète $\omega-3$ PNRR vaidmens suvokimą uždegiminiame procese: studijose nustatyta, jog būtent jie gali mažinti neutrofilų infiltraciją ir skatinti makrofagų atsaką, tad yra svarbūs ligų, kurioms būdingi ryškūs uždegimo požymiai, eigai [20,21]. Šie mediatoriai susiję ir su ląstelių membranose randamomis RR, todèl didinant jų kiekị žuvų taukais, galima kontroliuoti lipidų mediatorių sintezę bei funkciją [21,22]. T. Ishihara (2019) studijos duomenimis, EPR ir DHR poveikis uždegimo ląstelèms in vitro gali mažinti neutrofilų ir monocitų kiekị bei 
specifinių adhezinių molekulių sintezę [23]. Taip EPR ir DHR užtikrina optimalų fiziologinị imuninį atsaką, todèl greičiau balansuojama uždegimo raiška [21, 22, 23, 24].

PM žuvų taukų nauda kritinių būklių ir chirurginio profilio pacientams. Tyrimuose nagrinèta, ar žuvų taukais papildyti PM gerina abdominalinio, kardiochirurginio bei onkochirurginio profilio kritinès būklès pacientų ligos baigti. Dar ankstesneje A. R. Heller ir kt. (2006) daugiacentreje studijoje, aprépusioje 661 paciento duomenis, nustatyta, jog skiriant pakankamą žuvų taukų kiekị išvardyto profilio pacientams, mažejo infekcijų dažnis, antibiotikų poreikis, gydymo intensyviosios terapijos skyriuje trukmé, gerèjo išgyvenamumas [25]. Vèliau W. Manzanares ir kt. (2015) pastebejjo, jog PM papildymas žuvų taukais gerina pacientu imunologinių tyrimų rodiklius ir trumpina pooperacinio gydymo trukmę [26]. To paties autoriaus atlikta 733 pacientų duomenų analizè iš 10 įvairių šalių intensyviosios terapijos skyrių patvirtino, jog žuvų taukais papildytos lipidų emulsijos yra reikšmingai susijusios su sumažejusia infekcinių ligų rizika, MV poreikiu bei gydymo trukme [26]. Naujausiuose tyrimuose S. Honeywell ir kt. (2019) nustate, kad chirurginio profilio pacientams skiriami PM su žuvų taukais yra susiję su mažesne trigliceridų koncentracija kraujyje, geresniais uždegimo rodiklių ir kepenų fermentų tyrimų rezultatais [27]. Nors esamų tyrimų išvadų dar nepakanka tarptautinèms rekomendacijoms suformuoti dèl per mažos tyrimų imties, tačiau jau neabejotina, jog tokie PM intensyviosios terapijos ir chirurginio profilio pacientams yra ypač naudingi [13, 25, 26, 27, 28].

Žuvų taukais papildyto PM vartojimo saugumas. Diskutuojama, ar žuvų taukai yra saugūs pacientams. Išnagrinètų šaltinių duomenys patvirtina žuvų taukų saugumą ir tolerantiškumą, vartojant juos ilgą laiką [13,29]. H. Tian ir kt. (2013) atlikta 23 tyrimų metaanalize, nagrinejjusi 1503 intensyviosios terapijos ir chirurginio profilio pacientų ilgalaikị žuvų taukais papildyto PM vartojimą, žalingo poveikio nenustatė [30].

Žuvų taukų vartojimo PM farmakoekonominẻ nauda. L. Pradelli ir kt. (2014) atliko farmakoekonominị žuvų taukų naudos PM įvertinimą, remdamiesi Italijos, Prancūzijos, Vokietijos ir Jungtinès Karalystės ligoninių duomenimis. Nustatyta, jog vartojant žuvų taukais papildytus PM, sumažèjo antibiotikų poreikis ir gydymo ligoninèje trukmè dèl sumažèjusio infekcijų dažnio bei MV trukmès [31]. Atlikta išlaidų analizè parodè ir finansinę naudą - skiriant PM mišinius su žuvų taukais vienam intensyviosios terapijos skyriaus pacientui skirtingose šalyse sutaupyta 3972-4897 eurų [31].

\section{Išvados}

Intraveninès lipidų emulsijos su sojų aliejumi buvo parenterinių mišinių sudedamoji dalis. Yra svarių mokslinių irodymų, kad žuvų taukai ir juose vyraujančios $\omega-3$ polinesočiosios riebosios rūgštys yra vertingesnès, nei vis dar populiarūs parenteriniai mišiniai su sojų aliejaus $\omega-6$ polinesočiosiomis riebosiomis rūgštimis. Žuvų taukų vartojimas gali užtikrinti ypač raiškaus uždegimo proceso subalansavimą, tuo sumažinant antibiotikų poreikị, infekcinių ligų dažnị, mechaninès ventiliacijos, o kartu ir gydymo intensyviosios terapijos skyriuose bei ligoninėse trukmę, pagerinti kritinès būklès ir chirurginio profilio pacientų ligos baigti, sumažinti jų gydymo išlaidas.

\section{Literatūra}

1. Shah S, Hollands JM, Pontiggia L, Bingham AL. Impact of the time to initiation of parenteral nutrition on patient outcomes in critically ill adults. Nutrition and Metabolic Insights 2019;12:1178638819859315.

https://doi.org/10.1177/1178638819859315

2. Mayer K, Schaefer MB, Hecker M. Intravenous n-3 fatty acids in the critically ill. Current Opinion in Clinical Nutrition \& Metabolic Care 2019;22(2):124-128.

https://doi.org/10.1097/MCO.0000000000000550

3. Heidegger CP, Berger MM, Graf S, Zingg W, Darmon P, Costanza $\mathrm{MC}$ et al. Optimisation of energy provision with supplemental parenteral nutrition in critically ill patients: a randomised controlled clinical trial. The Lancet 2013;381(9864):385-393. https://doi.org/10.1016/S0140-6736(12)61351-8

4. Baiu I, Spain DA. Parenteral nutrition. JAMA 2019;321(21):2142. https://doi.org/10.1001/jama.2019.4410

5. Calder P, Waitzberg DL, Klek S, Martindale RG. Lipids in parenteral nutrition: biological aspects. Journal of Parenteral and Enteral Nutrition 2019. In press

https://doi.org/10.1002/jpen.1756

6. Gramlich L, Ireton-Jones C, Miles JM, Morrison M, PontesArruda A. Essential fatty acid requirements and intravenous lipid emulsions. Journal of Parenteral and Enteral Nutrition 2019;43:697-707. https://doi.org/10.1002/jpen.1537

7. Innes JK, Calder PC. Omega-6 fatty acids and inflammation. Prostaglandins, Leukotrienes and Essential Fatty Acids 2018;132:41-48.

https://doi.org/10.1016/j.plefa.2018.03.004

8. Kang JX, Weylandt KH. Modulation of inflammatory cytokines by omega-3 fatty acids. Lipids in Health and Disease. Subcellular Biochemistry 2008;49:133-143.

https://doi.org/10.1007/978-1-4020-8831-5_5

9. Feingold KR, Grunfeld C. Lipids: a key player in the battle 
between the host and microorganisms. Journal of Lipid Research 2012;53(12):2487-2489.

https://doi.org/10.1194/jlr.E033407

10. Nickels JD, Smith MD, Alsop RJ, Himbert S, Yahya A, Cordner D et al. Lipid rafts: buffers of cell membrane physical properties. The Journal of Physical Chemistry B 2019;123(9):20502056.

https://doi.org/10.1021/acs.jpcb.8b12126

11. Simopoulos AP. Importance of the ratio of omega-6/omega-3 essential fatty acids: evolutionary aspects. Omega-6/omega-3 essential fatty acid ratio: The Scientific Evidence. Karger Publishers 2003;92:1-22.

https://doi.org/10.1159/000073788

12. Meirer K, Steinhilber D, Proschak E. Inhibitors of the arachidonic acid cascade: interfering with multiple pathways. Basic \& Clinical Pharmacology \& Toxicology 2014;114(1):83-91 https://doi.org/10.1111/bcpt.12134

13. Mayer K, Schaefer MB, Seeger W. Fish oil in the critically ill: from experimental to clinical data. Current Opinion in Clinical Nutrition \& Metabolic Care 2006;9(2):140-148. https://doi.org/10.1097/01.mco.0000214573.75062.0a

14. Tilley SL, Coffman TM, Koller BH. Mixed messages: modulation of inflammation and immune responses by prostaglandins and thromboxanes. The Journal of Clinical Investigation 2001;108(1):15-23. https://doi.org/10.1172/JCI200113416

15. Medzhitov R. Origin and physiological roles of inflammation. Nature 2008;454:428-435.

https://doi.org/10.1038/nature07201

16. Cinel I, Opal SM. Molecular biology of inflammation and sepsis: a primer. Critical Care Medicine 2009;37(1):291-304. https://doi.org/10.1097/CCM.0b013e31819267fb

17. Adukauskienė D., Stankūnaitė J., Navickaitė S. Pasaulinei sepsio dienai 2016: sepsio ir sepsinio šoko diagnostikos naujienos pagal trečiajị tarptautinị sutarimą (sepsis-3). Sveikatos mokslai, 2016;26:173-177.

https://doi.org/10.5200/sm-hs.2016.112

18. Calder PC, Jensen GL, Koletzko BV, Singer P, Wanten GJ. Lipid emulsions in parenteral nutrition of intensive care patients: current thinking and future directions. Intensive Care Medicine 2010;36(5):735-749.

https://doi.org/10.1007/s00134-009-1744-5

19. Abbasoglu O, Hardy G, Manzanares W, Pontes-Arruda A. Fish oil - containing lipid emulsions in adult parenteral nutrition: a review of the evidence. Journal of Parenteral and Enteral Nutrition 2019;43(4):458-470.

https://doi.org/10.1177/0148607117721907

20. Im DS. Omega-3 fatty acids in anti-inflammation (pro-resolution) and GPCRs. Progress in Lipid Research 2012;51(3):232237.

https://doi.org/10.1016/j.plipres.2012.02.003
21. Calder PC. Omega-3 fatty acids and inflammatory processes: from molecules to man. Biochemical Society Transactions 2017;45(5):1105-1115.

https://doi.org/10.1042/BST20160474

22. Duvall MG, Levy BD. DHA-and EPA-derived resolvins, protectins, and maresins in airway inflammation. European Journal of Pharmacology 2016;785:144-155.

https://doi.org/10.1016/j.ejphar.2015.11.001

23. Ishihara T, Yoshida M, Arita M. Omega-3 fatty acid-derived mediators that control inflammation and tissue homeostasis. International Immunology 2019;31(9):559-567.

https://doi.org/10.1093/intimm/dxz001

24. Weylandt KH, Chiu CY, Gomolka B, Waechter SF, Wiedenmann B. Omega-3 fatty acids and their lipid mediators: towards an understanding of resolvin and protectin formation. Prostaglandins \& Other Lipid Mediators 2012;97(3-4):73-82.

https://doi.org/10.1016/j.prostaglandins.2012.01.005

25. Heller AR, Rössler S, Litz RJ, Stehr SN, Heller SC, Koch R, et al. Omega-3 fatty acids improve the diagnosis-related clinical outcome. Critical Care Medicine 2006;34(4):972-979. https://doi.org/10.1097/01.CCM.0000206309.83570.45

26. Manzanares W, Langlois PL, Dhaliwal R, Lemieux M, Heyland DK. Intravenous fish oil lipid emulsions in critically ill patients: an updated systematic review and metaanalysis. Critical Care 2015;19(1):167.

https://doi.org/10.1186/s13054-015-0888-7

27. Honeywell S, Zelig R, Rigassio Radler, D. Impact of intravenous lipid emulsions containing fish oil on clinical outcomes in critically ill surgical patients: a literature review. Nutrition in Clinical Practice 2019;34:112-122.

https://doi.org/10.1002/ncp.10224

28. Calder PC, Adolph M, Deutz NE, Grau T, Innes JK, Klek S, et al. Lipids in the intensive care unit: recommendations from the ESPEN Expert Group. Clinical Nutrition 2018;37(1):1-18. https://doi.org/10.1016/j.clnu.2017.08.032

29. Malinowski SS, Barber KE, Kishk OA, Mays AA, Jones SR, Turner AL et al. Effect of fish oil supplement administration method on tolerability and adherence: a randomized pilot clinical trial. Pilot and Feasibility Studies 2019;5(1):3.

https://doi.org/10.1186/s40814-018-0387-0

30. Tian H, Yao X, Zeng R, Sun R, Tian H, Shi C, et al. Safety and efficacy of a new parenteral lipid emulsion (SMOF) for surgical patients: a systematic review and meta-analysis of randomized controlled trials. Nutrition Reviews 2013;71(12):815-821. https://doi.org/10.1111/nure.12053

31. Pradelli L, Eandi M, Povero M, Mayer K, Muscaritoli M, Heller AR, et al. Cost-effectiveness of omega-3 fatty acid supplements in parenteral nutrition therapy in hospitals: a discrete event simulation model. Clinical Nutrition 2014;33(5):785-792. https://doi.org/10.1016/j.clnu.2013.11.016 
FISH OIL IMPORTANCE IN MODERN PARENTERAL NUTRITION FOR CRITICALLY ILL PATIENTS

\section{Adukauskienė, A. Jurgelènaitè, T. Vanagas}

Keywords: parenteral nutrition, fish oil, inflammation, critical condition.

Summary

Parenteral nutrition is the method to ensure optimal clinical nutrition especially of critically ill and surgical profile patients, this why scientific studies do analyse the importance of parenteral mixtures with fish oil use for receiving patients outcomes. According to studies conclusions these parenteral mixtures help to control inflammation in any critical condition when it is overexpressed. Also, studies have found out parenteral nutrition enriched with fish oil to be associated with better outcomes for critically ill patients as better immunological tests results, decreased rate of infections and need for antibiotics, reduced mechanical ventilation duration as treatment at intensive care unit and for post-operative patients, better survival have occured. In publications it has been declared about parenteral mixtures with fish oil to be safe ant tolerable in case of long term use. Data from Western Europe hospitals aimed to evaluate these parenteral mixtures from the pharmacoeconomic point: authors have reported lower expenses while using parenteral nutrition with fish oil for critically ill patients. In this paper we are seeking to attract attention to benefits of using parenteral mixtures enriched with fish oil for critically ill and post-surgical patients.

Correspondence to: akvile.jurgelenaite@gmail.com

Gauta 2020-02-20 